Proceeding of the $2^{\text {nd }}$ International Conference on Agriculture, Food Security and Safety, Vol. 2, 2021, pp. 15-28 Copyright $(\mathcal{C} 2021$ iConferences

ISSN 2682-7158

DOI: https://doi.org/10.32789/agrofood.2021.1002

\title{
Effect of Different Fertilizer Management on Water Quality in the Paddy Field
}

\author{
Norlida M.H' , Mohammad Aufa, M.B ${ }^{2}$, Muhammad Naim Fadzli A.R ${ }^{3}$, Mohd \\ Shahril Shah M.G ${ }^{2}$ and Czahari $\mathrm{M}^{1}$
}

\footnotetext{
${ }^{1}$ Soil, Water and Fertilizer Research Centre, Malaysian Agricultural Research and Development Institute (MARDI), Serdang, Selangor Malaysia, norlida@mardi.gov.my, czahari@mardi.gov.my

${ }^{2}$ Engineering Research Centre, Malaysian Agricultural Research and Development Institute (MARDI), Seberang Perai, Pulau Pinang, Malaysia, aufa@mardi.gov.my, shahril@mardi.gov.my
}

${ }^{3}$ Paddy and Rice Research Centre, Malaysian Agricultural Research and Development Institute (MARDI), Seberang Perai, Pulau Pinang, Malaysia, naim@mardi.gov.my, 


\title{
EFFECT OF DIFFERENT FERTILIZER MANAGEMENT ON WATER QUALITY IN THE PADDY FIELD
}

\begin{abstract}
Agricultural intensification is one of the major causes of water pollution. In recent decades, agricultural water quality degradation has become more severe, which in turn emphasizes the importance of improving and implementing sustainable agricultural practices. Precision agriculture variable rate fertilizer application technology is seen as a strategy to reduce environmental pollution caused by excessive fertilizer usage. Fertilizer input rate is altered within the field in response to factors affecting the optimal application rate. The objective of this study was to investigate the effects of uniform rate and variable-rate $(\mathrm{N})$ fertilizer management on surface water quality. Various physical and chemical water quality parameters at the water inlet, paddy field, irrigation canal, and drainage canals were also examined to evaluate seasonal water quality trends. Water sampling was carried out twelve times between September 2018 and July 2019, involving two cultivation seasons within a total of 60 hectares of paddy field in FELCRA Seberang Perak, Malaysia. All water quality measures fall within classes II to IV of the Malaysian National Water Quality Standards (NWQS) with the exception of P, Al, and Fe. In season one, $64 \%$ of $\mathrm{P}, 46 \%$ of $\mathrm{Al}$, and $18 \%$ of $\mathrm{Fe}$ concentrations were found to exceed NWQS Class IV. However, the percentages were lower compared to season two. During the monitoring period, the average concentration of nitrate and ammonia in variable-rate plots was lower than uniform rate plots in both seasons. Furthermore, temperature, Dissolved Oxygen (DO), Biochemical Oxygen Demand (BOD), Chemical Oxygen Demand (COD), $\mathrm{pH}, \mathrm{Cu}, \mathrm{Fe}, \mathrm{K}$, and $\mathrm{Mn}$ were significantly different between the two seasons of cultivation.
\end{abstract}

Keywords: surface runoff, precision farming, nutrient management

\section{Introduction}

Water pollution is an increasing global challenge, undermining economic growth as well as the socioenvironmental sustainability and health of people. Agricultural pressure on water quality originates from intensive crop planting, livestock farming, and aquaculture to meet increasing food demand related to population growth and mobility and changes in human dietary patterns (FAO 2018, UN Water 2009). Water quality degradation such as dam siltation caused by the mobilization of sediment due to erosion and irrigation using saline or brackish water has limited agricultural production worldwide (Mateo-Sagasta and Burke, 2010).

Agriculture intensification can result in negative environmental consequences, such as non-point source pollution (Lindquist, 2014). Although fertilizers are important materials to the production potential of agricultural land, which are used to increase production potential, maintain high yield, and product quality, it was found that applying quantities of fertilizer more than required actually harmed not only the crop production and potential yield but also the ecosystem (Gastal and Lemaire, 2002). The intensive application of fertilizer for crops is responsible for nitrate-N contamination in both groundwater and surface waters, resulting in environmental and ecological destruction and may pose potential hazards to human health (Qia et al., 2020). Pesticide accumulation (DDT and many 
organophosphates) and heavy metals in water and the food chain have demonstrated many ill effects on humans (Mateo-Sagasta and Burke, 2010). This problem will aggravate if the use of these agrochemicals is unregulated. The long term impact on water quality due to the widespread application of these chemicals should not be underestimated (FAO, 1999).

In the Malaysian agriculture sector, the biggest water user is the rice irrigation sub-sector at 8,266 million cubic metres (MCM) in 2010, forming 55.9\% of the total water demand and $64.3 \%$ of the total agriculture water demand (ASM, 2017). As the demand for rice consumption increases, concerns over intensive use of nutrients and poor water quality resulting from agriculture intensification have arisen in recent decades (DOE, 2015). Paddy fields account for a significant share of chemical fertilizer consumption among agriculture crops. Water from the paddy field is usually discharged into the drainage system without any treatment, and such residues of the applied agrochemicals would pollute both the drains and the receiving waters. This complex relationship between agriculture and water quality degradation has placed increased pressure on agriculture to incorporate improved practices to sustain agricultural productivity and enhance environmental quality (Zebarth et al., 2008).

Precision farming is one of the potential agriculture management systems to reduce non-point pollution from rice fields to the water environment. Precision farming is the reorientation of traditional farming to a farm management system that takes into account the variability of natural resources in order to protect the environment and improve farmers' profitability (Mohd Noor et al., 2005). Variable-rate technology (VR) is one such component in precision farming (Sawyer, 1994; Schumann, 2010; Bakhtiari and Hematian, 2013). The VR can be applied for crop inputs such as fertilizers, herbicides, and seeds.

High-speed computers, reliable Global Positioning System (GPS) receivers, Geographic Information Systems (GIS), remote sensing, yield or soil maps, actuators, and electronic sensors are used to measure crop properties in real-time (Schumann, 2010). In the variable rate application technology (VRT), crop production input rate is adjusted within fields in response to spatially variable factors (Sawyer, 1994). Spatial mapping was used combined with field instruments for the precision delivery of nutrients. This precision farming technology could potentially be used to make the rice production industry more efficient (Abu Bakar et al., 2019). Numerous research elements of precision farming, such as soil fertility, seed and fertilizer application technology, field level, pest, and disease, have been considered in previous research (Abu Hassan et al., 2001; Abu Hassan et al. 2009; Chan, 2013: Mohd Syaifudin et al., 2016). However, the impact of these practices on water quality issues, ecosystem, and groundwater reservoirs is not extensively studied.

The objective of this study was to evaluate the water quality trend in the FELCRA Seberang Perak rice field affected by different fertilizer management practices using Malaysian National Water Quality Standards. Water quality changes in the rice field were monitored by measuring several physical and chemical water quality parameter at several sampling points throughout the planting season. Water quality sampling was done from September 2018 and June 2019. The collected data were statistically analyzed, and results were compared with the National Water Quality Standards (NWQS). The results obtained from this study will offer a better insight into variable-rate fertilizer management systems and help enhance the management of agroecosystems for water quality pollution control and water resource conservation. 


\section{Materials and Method}

\section{Description of the study site}

Seberang Perak Federal Land Consolidation and Rehabilitation Authority (FELCRA) rice field is located at $4^{0} 7^{\prime} \mathrm{N}$ and $101^{\circ} 4^{\prime} \mathrm{E}$. This region is characterized by a hot and humid monsoon climate with a total rainfall of $1625.5 \mathrm{~mm}$ during two seasons of crop cultivation (September -December 2018: March -June 2019). Season 2/2018 showed higher rainfall (1015.5 mm) compared with season 1/2019 $(637 \mathrm{~mm})$. Table 1 shows the total monthly rainfall and the number of rainy days in the study area. Rainfall data were obtained from the nearest JPS Hydrological Station, Sg Dedap. Agriculture is the main economic activity among the residents in the surrounding area. The average yield of rice was $3.7 \mathrm{t} \mathrm{ha}^{-1}$ and is considered below the national average yield (MOA, 2016). The water source for irrigation is from the Perak River, and drainage water from the estate flows into the downstream section of Sungai Dedap.

Table 1: Total monthly rainfall and number of rainy days in the study area

\begin{tabular}{llllllllll}
\hline & \multicolumn{3}{c}{ Season $2 / 2018$} & & \multicolumn{3}{c}{ Season 1/2019 } \\
\cline { 2 - 4 } \cline { 8 - 10 } & Sept. & Oct. & Nov & Dec. & & March & April & May & June \\
Total $(\mathrm{mm})$ & 191 & 275.5 & 165 & 384 & & 149.5 & 268.5 & 60.5 & 158.5 \\
Number of rainy days & 14 & 17 & 21 & 20 & & 13 & 18 & 16 & 12 \\
\hline
\end{tabular}

The cultivated area in FELCRA is about 4000 ha, and the rice plantation was divided into several blocks for easy management purposes. Block L3 comprises of 60 ha cultivation area, divided into plots of about one hectare each, was chosen for this research. Figure 1 shows the location of the study area.
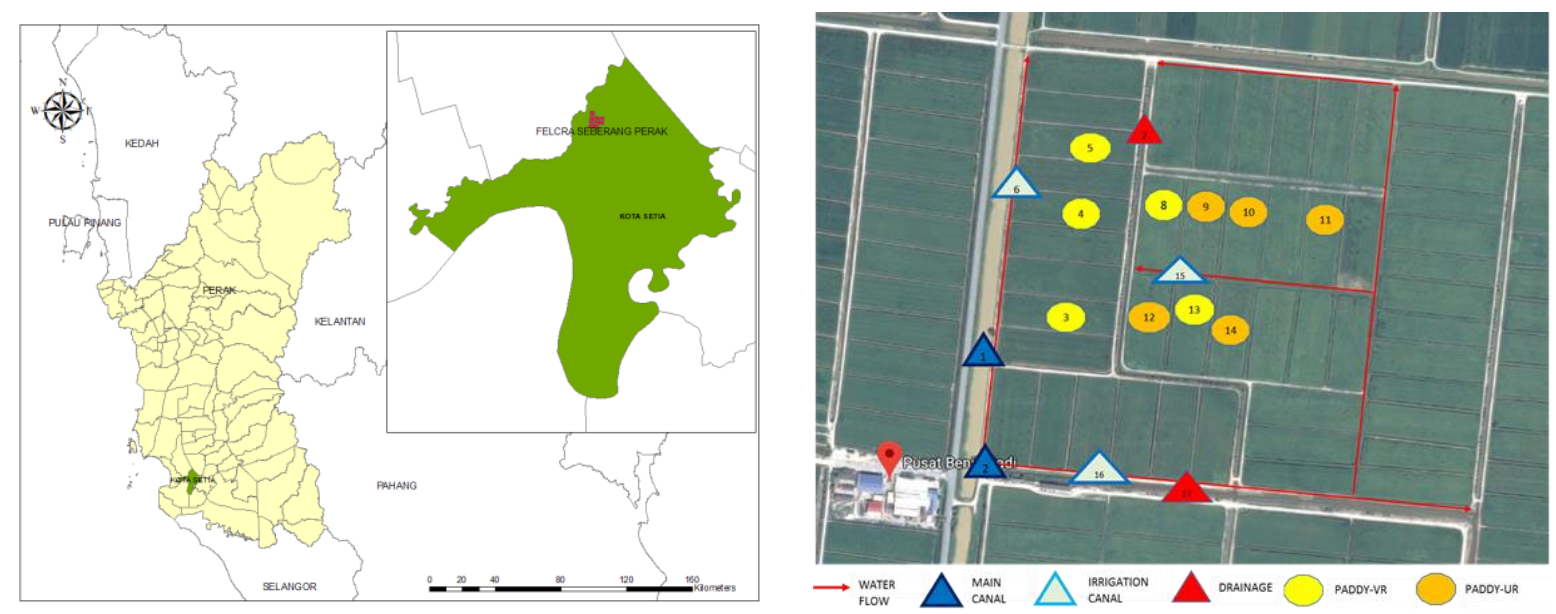

Figure 1 Location map of FELCRA Seberang Perak and sampling points.

Rice planting season in Block L3 started from September to December (Season 2/2018) and March to June (Season 1/2019. Rice variety MR 220 CL2 was planted between 100-110 days throughout the season. The rice cropping system and sampling dates are shown in Table 2. 
Norlida, M.H. / Effect of different fertilizer management on water quality in the paddy field

Table 2:Rice cropping system and sampling date

\begin{tabular}{lll}
\hline Month & Field Management & Sampling Date \\
\hline $\begin{array}{l}\text { Season 2/2018 } \\
\text { September }\end{array}$ & Sowing (11/9) & $25 / 9(14$ DAS) \\
& First Fertilizer (26/9) & \\
October & Second Fertilizer (10/10) & $2 / 10(21$ DAS) \\
& Third Fertilizer (26/10) & $17 / 10$ (36 DAS) \\
& & $30 / 10(49$ DAS) \\
November & Fourth Fertilizer (15/11) & $22 / 11$ (72 DAS) \\
December & Harvesting & $6 / 12(86$ DAS) \\
Season 1/2019 & & \\
March & Sowing (20/3) & $14 / 3$ (-6 DAS) \\
April & First fertilizer (4-5/4) & $9 / 9(20$ DAS) \\
& Additional fertilizer (16-17/4) & $22 / 4(33$ DAS) \\
May & Additional fertilizer (4-5/5) & $9 / 5(57$ DAS) \\
& Additional fertilizer (24-25/5) & $28 / 5(69$ DAS) \\
June & Harvesting (28/6) & $13 / 6$ (85 DAS) \\
\hline
\end{tabular}

*DAS: Day after Sowing

Fertilizer was applied four times throughout the season. The management of fertilizer was divided into two approaches, namely precision farming variable rate fertilizer (VR) and normal practice uniformed rate fertilizer (UR). Several plots were selected for both nutrient management. The UR plots were managed by pre-determining the rate of fertilizer, and the VR plots were managed by using several rates of fertilizer based on measured crop canopy throughout the rice planting season. The rate of fertilizer was shown in Table 3. In both seasons, the UR plots received 104:35.5:90 NPK kg ha ${ }^{-1}$. In season 2/2018, the total fertilizer applied in VR plots was 101:37.54: 105.44 NPK kg ha-1 and in season 1/2019 was 99.5:32.86:86.12 NPK kg ha-1.

Table 3: The amount of nutrient input $\left(\mathrm{kg} \mathrm{ha}^{-1}\right)$ for different fertilizer managements for two seasons of rice cultivation

\begin{tabular}{|c|c|c|c|c|c|c|c|c|c|c|c|c|}
\hline & \multicolumn{3}{|c|}{$1^{\text {st }}$ Fertilizer } & \multicolumn{3}{|c|}{$2^{\text {nd }}$ Fertilizer } & \multicolumn{3}{|c|}{$3^{\text {rd }}$ Fertilizer } & \multicolumn{3}{|c|}{$4^{\text {th }}$ Fertilizer } \\
\hline & $\mathrm{N}$ & $\mathrm{P}$ & $\mathrm{K}$ & $\mathrm{N}$ & $\mathrm{P}$ & $\mathrm{K}$ & $\mathrm{N}$ & $\mathrm{P}$ & $\mathrm{K}$ & $\mathrm{N}$ & $\mathrm{P}$ & $\mathrm{K}$ \\
\hline \multicolumn{13}{|c|}{ Season $2 / 2018$} \\
\hline UR & 24.5 & 21.7 & 14 & 36.8 & 0 & 0 & 25.5 & 4.5 & 37.5 & 18 & 9 & 39 \\
\hline VR & 24.5 & 21.7 & 14 & 24.5 & 0 & 0 & 32.3 & 5.7 & 47.5 & 20.3 & 10.14 & 43.94 \\
\hline \multicolumn{13}{|c|}{ Season $1 / 2019$} \\
\hline UR & 24.5 & 21.7 & 14 & 36.8 & 0 & 0 & 25.5 & 4.5 & 37.5 & 18 & 9 & 39 \\
\hline VR & 24.5 & 21.7 & 14 & 30.8 & 0 & 0 & 33.7 & 5.94 & 49.5 & 10.5 & 5.22 & 22.62 \\
\hline
\end{tabular}

\section{Water sampling points}

Water sampling was conducted twelve times during the planting season at 3-7 days after fertilization except for the first and last sampling. In this study, there were 17 sampling points located in the main canal, irrigation canal, rice plot, and drainage. Sampling locations were shown in Figure 1. Water quality was monitored for each sampling point, and collected samples were analyzed for chemical water quality parameters. 


\section{Water quality sampling and analysis}

In situ physical water quality parameter (temperature, dissolved oxygen $\mathrm{DO}, \mathrm{pH}$ ) were measured using Multiparameter (YSI 6820, USA). The measurements were taken three times at each sampling point. Sampling was done from 9-11 in the morning. Before conducting field sampling, all sensors were calibrated relative to their corresponding standard. Water samples for laboratory analysis were collected manually in HDPE bottles pre-soaked in HCL for 24 hours and rinsed with deionized water. Surface water samples were collected directly using bottle samples. Samples for BOD analysis were collected using a glass amber bottle. Samples were taken in three replicates for every sampling point. Samples have to be kept in a cooler box filled with ice during transportation and immediately stored in a $4^{\circ} \mathrm{C}$ chiller in the laboratory before it was analyzed within 48 hours. Water samples had to be removed from the refrigerator and placed for two hours at room temperature for conditioning prior to the analysis. $\mathrm{Al}, \mathrm{Cu}, \mathrm{Fe}, \mathrm{K}, \mathrm{Mg}$, and $\mathrm{Mn}$, were analyzed using Inductively Coupled Plasma (Perkin Elmer Optima 7300 DV, USA) within 28 days. Table 4 summarized analytical methods for chemical analysis in the laboratory. All methods for analysis were based on Standard Methods (APHA, 2005; USEPA, 1983). Statistical analysis of ANOVA (sampling time, sampling points, and season with water quality) were performed using SPSS software (version 23, USA).

Table 4: Analytical method used in the chemical analysis at the laboratory

\begin{tabular}{|c|c|c|c|}
\hline Parameter & Method & Equipment & Reference \\
\hline BOD $(\mathrm{mg} / \mathrm{L})$ & 5 day BOD & $\begin{array}{l}\text { Incubator HACH, USA } \\
\text { YSI Pro ODO, USA }\end{array}$ & APHA, 2005 \\
\hline $\mathrm{COD}(\mathrm{mg} / \mathrm{L})$ & Reactor Digestion & Digester Reactor DRB 200, USA & USEPA, 1983 \\
\hline $\begin{array}{l}\text { Ammoniacal Nitrogen } \\
(\mathrm{mg} / \mathrm{L})\end{array}$ & Nessler & Spectrophotometer HACH 3900, USA & APHA, 2005 \\
\hline Nitrate $(\mathrm{mg} / \mathrm{L})$ & Cadmium Reduction & Spectrophotometer HACH 3900, USA & APHA, 2005 \\
\hline Phosphate (mg/L) & Ascorbic Acid & Spectrophotometer HACH 3900, USA & APHA 2005 \\
\hline TSS (mg/L) & Photometric & Spectrophotometer HACH 3900, USA & APHA 2005 \\
\hline
\end{tabular}

\section{Water Quality Classification}

In Malaysia, water quality classification using National Water Quality Standards (NWQS) is the most commonly accepted standards (DOE, 2017). The NWQS comprises over 120 physicochemical and biological parameters and is defined by six classes (I, IIA, IIB, III, IV, and V) for the classification of water bodies based on the descending order of water quality from Class I to Class V. Details of the classifications is shown in Appendix 1. Water quality data in this study will be classified using this classification to determine the level of water pollution. 


\section{Result and Discussion}

Water quality data for two seasons of rice cultivation are summarized in Table 5, and water quality in the inlet, irrigation canal, outlet, and rice plot is illustrated in Appendix 2 to evaluate the overall water pollution level in Blok L3. Table 6 shows ANOVA results. Results on several water quality parameters will be discussed in general, while results on nutrient concentrations in rice plots with different fertilizer management will be discussed further and highlighted in this paper due to their significance with the objective of this paper. In general, average temperature, DO, BOD, ammonia, $\mathrm{pH}, \mathrm{Cu}, \mathrm{K}$, and $\mathrm{Mg}$ in season 2/2018 were higher compared to season 1/2019. Results also show that in the two planting seasons, temperature, $\mathrm{DO}, \mathrm{BOD}, \mathrm{COD}, \mathrm{pH}, \mathrm{Cu}, \mathrm{Fe}, \mathrm{K}$, and $\mathrm{Mn}$ were significantly different. All parameters were significantly different with sampling time except for $\mathrm{pH}$. All parameters except for nitrate, $\mathrm{Fe}, \mathrm{K}$, and $\mathrm{Mn}$ were significantly different with sampling location.

Table 5: Water quality for two seasons of rice cultivation

\begin{tabular}{lccc}
\hline Parameter & Season $2 / 2018$ & Season $1 / 2019$ & Class IV NWQS \\
\hline & & & NA \\
Temperature $\left({ }^{\circ} \mathrm{C}\right)$ & $29.06 \pm 2.4$ & $28.23 \pm 1.26$ & $<3$ \\
DO $(\mathrm{mg} / \mathrm{L})$ & $4.87 \pm 3.6$ & $2.68 \pm 2.25$ & 12 \\
$\mathrm{BOD}(\mathrm{mg} / \mathrm{L})$ & $2.65 \pm 1.83$ & $1.71 \pm 1.03$ & 100 \\
$\mathrm{COD}(\mathrm{mg} / \mathrm{L})$ & $13.84 \pm 16.4$ & $20.53 \pm 18.97$ & 2.7 \\
Ammoniacal Nitrogen $(\mathrm{mg} / \mathrm{L})$ & $0.64 \pm 1.27$ & $0.50 \pm 0.81$ & $5-9$ \\
$\mathrm{pH}$ & $6.91 \pm 0.6$ & $6.53 \pm 0.42$ & 5 \\
Nitrate $(\mathrm{mg} / \mathrm{L})$ & $1.06 \pm 2.07$ & $2.12 \pm 4.84$ & 0.2 \\
$\mathrm{Phosphate}(\mathrm{mg} / \mathrm{L})$ & $0.47 \pm 0.46$ & $0.64 \pm 0.68$ & 0.5 \\
$\mathrm{Al}(\mathrm{mg} / \mathrm{L})$ & $3.13 \pm 4.9$ & $4.53 \pm 7.91$ & 0.2 \\
$\mathrm{Cu}(\mathrm{mg} / \mathrm{L})$ & $0.01 \pm 0.05$ & $0.003 \pm 0.002$ & 5 \\
Fe (mg/L) & $2.74 \pm 2.8$ & $5.32 \pm 5.3$ & NA \\
$\mathrm{K}(\mathrm{mg} / \mathrm{L})$ & $9.71 \pm 6.12$ & $2.91 \pm 3.22$ & NA \\
$\mathrm{Mg}(\mathrm{mg} / \mathrm{L})$ & $3.20 \pm 1.97$ & $2.58 \pm 2.36$ & 0.2 \\
$\mathrm{Mn}(\mathrm{mg} / \mathrm{L})$ & $0.01 \pm 0.14$ & $0.02 \pm 0.03$ & \\
\hline
\end{tabular}

NA: Value not available in the standard

Table 6: ANOVA for water quality with regard to seasonal variation, sampling points, and sampling time

\begin{tabular}{lccc}
\hline & Season & Sampling points & Sampling time \\
\hline Temperature $\left({ }^{\circ} \mathrm{C}\right)$ & $8.46^{*}$ & $4.0^{*}$ & $6.55^{* * *}$ \\
DO $(\mathrm{mg} / \mathrm{L})$ & $23.48^{* * *}$ & $9.73^{* * *}$ & $5.36^{* * *}$ \\
$\mathrm{BOD}(\mathrm{mg} / \mathrm{L})$ & $18.02^{* * *}$ & $2.70^{*}$ & $3.6^{*}$ \\
$\mathrm{COD}(\mathrm{mg} / \mathrm{L})$ & $5.47 *$ & $5.7 * * *$ & $12.30^{* * *}$ \\
$\mathrm{Ammoniacal} \mathrm{Nitrogen}(\mathrm{mg} / \mathrm{L})$ & $\mathrm{ns}$ & $3.16^{* *}$ & $4.18^{* *}$ \\
$\mathrm{pH}$ & $22.97 *$ & $12.9^{* * *}$ & $\mathrm{~ns}$ \\
Nitrate $(\mathrm{mg} / \mathrm{L})$ & $\mathrm{ns}$ & $\mathrm{ns}$ & $4.09^{*}$ \\
$\mathrm{Phosphate}(\mathrm{mg} / \mathrm{L})$ & $\mathrm{ns}$ & $3.09 *$ & $6.52^{*}$ \\
$\mathrm{Al}(\mathrm{mg} / \mathrm{L})$ & $\mathrm{ns}$ & $3.49 * *$ & $4.62^{*}$ \\
$\mathrm{Cu}(\mathrm{mg} / \mathrm{L})$ & $40.84 * * *$ & $5.87 * *$ & $6.04 * * *$ \\
$\mathrm{Fe}(\mathrm{mg} / \mathrm{L})$ & $12.67 * * *$ & $\mathrm{~ns}$ & $8.72^{* * *}$
\end{tabular}


Norlida, M.H. / Effect of different fertilizer management on water quality in the paddy field

\begin{tabular}{lccc}
$\mathrm{K}(\mathrm{mg} / \mathrm{L})$ & $87.55^{* * *}$ & $\mathrm{~ns}$ & $14.36^{* * *}$ \\
$\mathrm{Mg}(\mathrm{mg} / \mathrm{L})$ & $\mathrm{ns}$ & $21.04 *$ & $7.61 * * *$ \\
$\mathrm{Mn}(\mathrm{mg} / \mathrm{L})$ & $5.38^{*}$ & $\mathrm{~ns}$ & $9.42^{* * *}$ \\
\hline \multicolumn{2}{c}{ ns values are statistically not significant, ${ }^{*}$ values are statistically significant at $\mathrm{p}<0.05, * *$} \\
\\
values are statistically significant at $\mathrm{p}<0.01, * * *$ values are statistically significant at \\
$\mathrm{p}<0.0001$
\end{tabular}

\section{Water quality concentration in comparison to Malaysian Nation Water Quality Standards}

Generally, water quality in the study complies with Class IV NWQS standard (suitable for irrigation) except for a few parameters such as $\mathrm{Al}, \mathrm{Fe}$, and phosphate. In season one, $64 \%$ of phosphate, $46 \%$ of $\mathrm{Al}$, and $18 \%$ of $\mathrm{Fe}$ concentrations were found to exceed NWQS Class IV; however, the percentage was lower compared to season two. Season two resulted in $86 \%$ of phosphate, $75 \%$ of $\mathrm{Al}$, and $38 \%$ Fe, exceeding Class IV NWQS.

In both seasons of rice cultivation, the percentage of $\mathrm{P}$ detected in surface water exceeded the 0.2 $\mathrm{mg} / \mathrm{L}$ NWQS for irrigation. When the use of agricultural inputs containing phosphate exceeds the intake by crops, excess phosphate will be stored in the soil. This excess phosphate is closely related to the loss of phosphate through surface runoff and increases the potential for eutrophication in surface water sources. This indicates that phosphate is very easily released into the environment compared to other nutrients (Wu et al., 2016)

Aluminum is a metal easily obtained from the earth's crust but is not needed in large quantities by plants. High $\mathrm{Al}$ concentrations were found at several sampling points in the water inlet, rice plots, and outlets. The high concentration at the inlet may be due to industrial and agricultural activities around the water source of the Perak River. In general, the effect of Al toxicity on rice crops is root damage which will interfere with the process of nutrient transfer. However, the relationship between the continuous usages of irrigation water that has a high $\mathrm{Al}$ value with the growth of crops in areas of soil that have a normal $\mathrm{pH}$ is difficult to prove. This is because the toxicity effect of $\mathrm{Al}$ on plants is greatly influenced by the $\mathrm{pH}$ of the soil. The effect of $\mathrm{Al}$ toxicity on crops will be serious on acidic soil conditions ( $\mathrm{ph}<5.5$ ) or alkaline soils ( $\mathrm{ph}>8$ ) (Department of Water Affairs and Forestry, 1996)

Fe value in season 1/2019 was found slightly higher than the NWQS standard for irrigation. Fe toxicity is primarily caused by the toxic effects of excessive Fe uptake due to the large concentration of $\mathrm{Fe}$ in the soil solution. Land preparation and flooding before the planting season were the possible cause of high $\mathrm{Fe}$. Fe is a concern in rice cultivation, especially in the early growing stage, as recently transplanted seedlings may be affected when large amounts of $\mathrm{Fe}^{2+}$ accumulate immediately after flooding (Doberman and Fairhurst, 2000). 


\section{Temporal variation of water quality in rice plot}

The average concentration of ammonia, phosphate, and nitrate in rice plots with two different fertilizer management for two seasons of cultivation were illustrated in Figure 2.
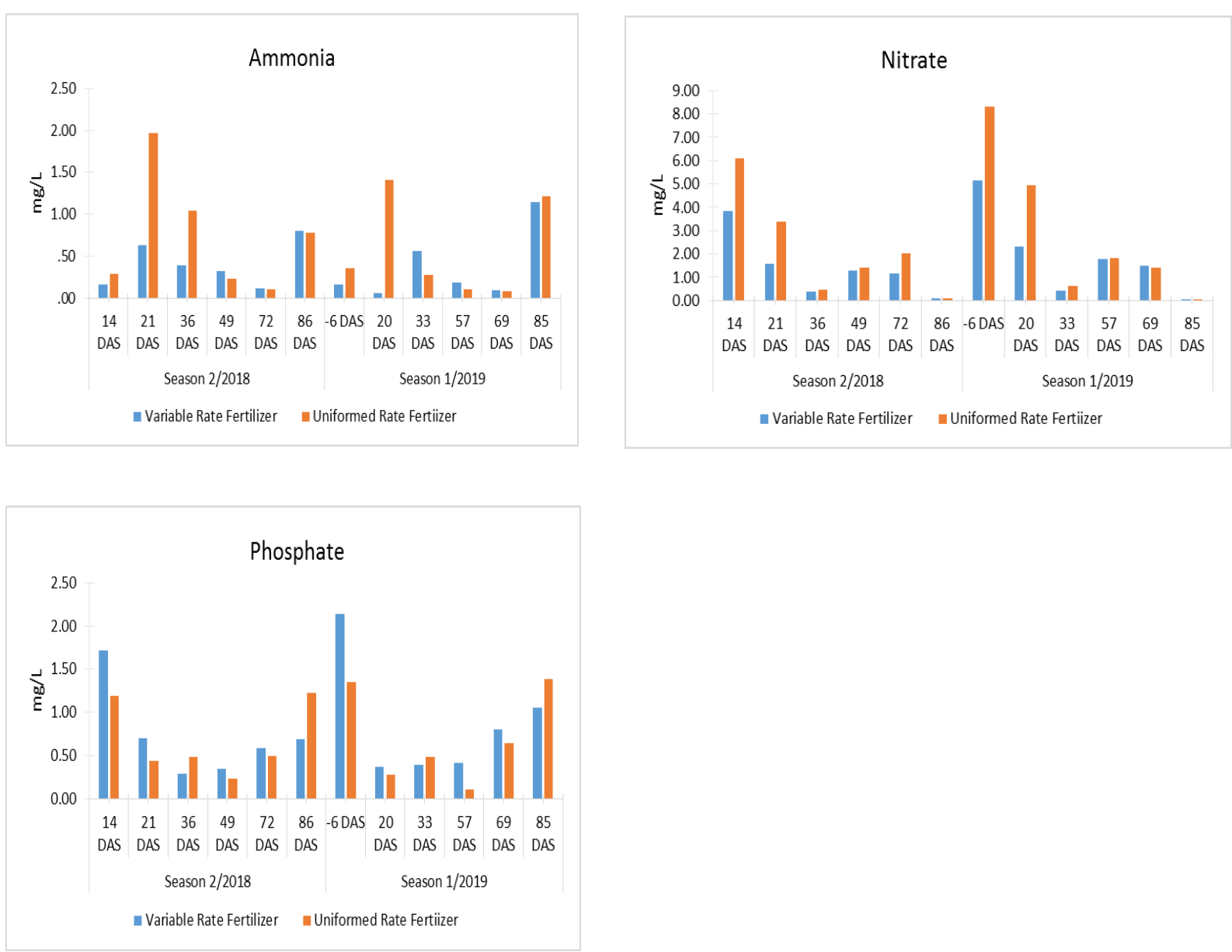

Figure 2 Water quality in rice plot with different fertilizer management in two seasons of cultivation

Water quality in both VR and UR sampling plots have different variations in both seasons. Average nitrate concentrations were between 0.01 to $34.27 \mathrm{mg} / \mathrm{L}$. Both seasons showed high concentrations of nitrate during the first sampling activities. Nitrate water quality in both VR and UR sampling plots has significant differences with sampling time. During the first sampling, the field was under flooded condition, and rice was in the vegetative growth stage. Earlier studies have shown that the amount of $\mathrm{N}$ and $\mathrm{P}$ lost through runoff and leaching are closely related to the water management measures (Yang, 2013). Average nitrate concentration in VR plots was lower compared to UR in both seasons. Nitrate concentrations in UR and VR were significantly different with both season and sampling time.

Average ammonia concentrations in both UR and VR were between 0.01 to $4.67 \mathrm{mg} / \mathrm{L}$. Average ammonia was higher in season 2/2018 compared with season 1/2019. Both seasons showed a similar trend of high concentration of ammonia during the second sampling activities. The concentrations gradually decreased and peaked again at the end of planting season, but the concentrations were 
below the highest concentration found at the second sampling. This trend was similar to findings by (Chen, 2013) who found that concentrations of nitrogen were high in the early stage of basal fertilizer application but subsequently decreased until the tillering fertilization and panicle fertilization rose again but were much lower than those in the early stage of basal fertilizer application. Ammonia concentrations in both VR and UR sampling plots have significant differences with sampling time.

In both seasons, the UR plots received a total of $104 \mathrm{~N} \mathrm{~kg} \mathrm{ha}^{-1}$. In season 2/2018, the total fertilizer applied in VR plots was $101.6 \mathrm{~N} \mathrm{~kg} \mathrm{ha}^{-1}$, and $99.5 \mathrm{~N} \mathrm{~kg} \mathrm{ha}^{-1}$ was applied in season $1 / 2019$. There was a 3\% reduction of total $\mathrm{N} \mathrm{kg} \mathrm{ha}^{-1}$ fertilizer in the VR plot in season 2/2018 and a 5\% reduction in season 1/2019 compared with UR plots. Results found that the different rate of $\mathrm{N}$ was not significant with nitrate and ammonia concentration in water. This was probably because $\mathrm{N}$ is susceptible to losses in the rice ecosystem, and it disappeared from the rice root zone within a week or two of the soil being flooded. Prediction of pollution potential of nitrate- $\mathrm{N}$ is further complicated by different variables of soils, irrigation water management, and the complex set of $\mathrm{N}$-transformation processes in rice fields (Chowdary et al., 2004).

Phosphate average concentration in rice plots was between 0.01 to $4.17 \mathrm{mg} / \mathrm{L}$. The mean phosphate value in the study was $0.71 \mathrm{mg} / \mathrm{L}$. Phosphate in both VR and UR plots showed significant differences within sampling time. Phosphate in this study was generally higher during the early growing season due to the fertilization process, decreased gradually, and increased drastically towards the end of the season. Rice P uptake could vary according to the rice yield, which was largely influenced by nitrogen availability (Doberman and Fairhurst, 2000). Excess accumulation of the soil P results in a loss of P into the environment. (Nagumo et.al, 2013). The average concentration of phosphate in season 1/2019 were higher compared with season $2 / 2018$. In both seasons, the UR plots received $35.3 \mathrm{P} \mathrm{kg} \mathrm{ha}^{-1}$. In season $2 / 2018$, the total fertilizer applied in VR plots was $37.54 \mathrm{P} \mathrm{kg} \mathrm{ha}^{-1}$ and in season $1 / 2019$ was $32.86 \mathrm{P} \mathrm{kg} \mathrm{ha}^{-1}$. There was a $6 \%$ increase of total $\mathrm{P} \mathrm{kg} \mathrm{ha}{ }^{-1}$ fertilizer in the VR plot in season $2 / 2018$ and a 7\% reduction in season 1/2019 compared with UR plots. Results found that the different rate of $\mathrm{P}$ was not significant with phosphate concentration in water.

\section{Conclusion}

The influence of different fertilizer management practices on water quality for two rice growing seasons was determined using the Malaysian water quality standard. Water quality sampling and analysis were conducted in seventeen sampling points located at Block L3A FELCRA Seberang Perak. Generally, water quality in the study complies with Class IV NWQS standard (suitable for irrigation) except for Al, Fe, and Phosphate. In season one, 64\% of Phosphate, 46\% of Al, and 18\% of Fe concentrations are found to exceed NWQS Class IV; however, the percentage was lower compared to season two. Season two resulted in $86 \%$ of Phosphate, $75 \%$ of $\mathrm{Al}$, and $38 \%$ of $\mathrm{Fe}$, exceeding Class IV NWQS. Results also show that in the two planting seasons, temperature, DO, $\mathrm{BOD}, \mathrm{COD}, \mathrm{pH}, \mathrm{Cu}, \mathrm{Fe}, \mathrm{K}$, and $\mathrm{Mn}$ were significantly different. All parameters were significantly different with sampling time except for $\mathrm{pH}$. All parameters except for nitrate, Fe, $\mathrm{K}$, and $\mathrm{Mn}$ were significantly different with sampling location. Results found that clean irrigation water used in rice field decreased in water quality due to planting activities, including land preparation, agriculture input application, and irrigation throughout the planting season. This study also found that although the level of ammonia and nitrate was lower in the VR plot in both seasons of rice cultivation, there 
was no significant difference between water quality parameters and different fertilizer management. However, this study was limited to evaluate surface water quality based on manual sampling during two seasons of rice plantation in the study area. Further research to quantify water and nutrient balance in both nutrient management practices, identify suitable, cost-effective water quality monitoring strategy and implement practical mitigation action to reduce water pollution into surface water is strongly recommended. Lastly, governance, legislation, and policy enforcement by respective authorities are needed to reduce water pollution from agriculture to achieve the National Water Resources Policy goal and the Malaysian Government's 11 $11^{\text {th }}$ Development Plan for sustainable agriculture.

\section{Acknowledgements}

This research was funded by the Malaysian Government's 11th Development Fund in Precision Farming (RMK 11 - PRS 420). The author would like to thank MARDI staff Mr. Muhamad Hadatulaswad Ramli, Mr. Azrizal Ahmad Rashdi for their help in sampling and analysis, and Mrs. Hasliana Kamaruddin in producing the location map.

\section{References}

Abu Bakar, B., Abd. Rahman, M.S., Rahim, H., Abd. Rani, M.N.F., Ghazali, M.S.S., Mohd. Bookeri M. A., Ahmad, M.T., Teoh, C.C., Bujang, A.S., Abdullah, M.Z.K. and Ismail, R..2020. Saving Fertilizer in Malaysia's Large-Scale Paddy Production through Precision Farming, FFTC Agricultural Policy Platform, Malaysian Agricultural Research and Development Institute, Serdang, Malaysia,

Abu Hassan, D., 2001, monitoring crop canopy development for nutrient management. Proceeding National Conference on Agriculture and Food Mechanization, Kuala Lumpur, Malaysia, October, pp. 450-453.

Abu Hassan, D., Ayob, A. H., Shahril Shah, M.G. S, Radzali, M, and Rukunudin, I.H., 2009, Package Technology for Variable Rate Fertilizer Application. Proceeding National Conference on Agriculture and Food Mechanization, Melaka, Malaysia, June, pp.278-281.

Akademi Sains Malaysia (ASM), 2017, Agriculture Water Service for AgriBusiness (Kuala Lumpur: ASM Publisher)

American Public Health Association (APHA), 2005, Standard Method for the Examination of Water and Wastewater. $19^{\text {th }}$ Edition. (Washington, APHA, AWWA and AWPFC).

Bakhtiari, A. A. and Hematian, A., 2013. Precision Farming Technology, Opportunities and Difficulty. International Journal for Science and Emerging Technologies with Latest Trends, 5(1): 1-14.

Chan, C.W., 2013, Precision Farming: The Way Forward in Mechanized Agriculture, (Serdang: MARDI).

Chen, S.K., Jang, C.S., Chen S.M and Chen K.C, 2013. Effect of N-fertilizer application on return flow water quality from a terraced paddy field in Northern Taiwan. Paddy Water Environ. 11:123-133.

Chowdary, N.H., Rao, V.M. and Sarma, P. B. S., 2004, a coupled soil water and nitrogen balance model for flooded rice fields in India. Agric. Ecosyst. Environ. 103:425-441.

Department of Water Affairs and Forestry, 1996, South African Water Quality Guidelines (2 ${ }^{\text {nd }}$ Edition). Volume 4: Agricultural Use: Irrigation, edited by Holmes, S., (South Afrika: CSIR Environmental Services). 
Norlida, M.H. / Effect of different fertilizer management on water quality in the paddy field

Department of Environment (DOE), 2015, Malaysia Environment Quality Report 2015, (Kuala Lumpur: Department of Environment, Ministry of Natural Resources and Environment).

Department of Environment (DOE), 2017, Malaysia Environment Quality Report 2017. (Kuala Lumpur: Department of Environment, Ministry of Natural Resources and Environment).

Doberman, A, and Fairhurst, T.H., 2000, Rice: Nutrient Disorder and Nutrient Management Handbook series. (Philippines: Potash \& Phosphate Institute (PPI), Potash \& Phosphate Institute of Canada (PPIC) and International Rice Research Institute).

Food and Agriculture Organization (FAO), 1999, Water quality management and control of water pollution, Proceedings of a Regional Workshop, Bangkok, Thailand, October.

Gastal, F., and Lemaire, G., 2002, N uptake and distribution in crops: an agronomical and ecophysiological perspective, Journal of Experimental Botany, 53(370), 789-799.

Lindquist, B. A., 2014, Nutrients and Sediments in Surface Runoff Water from Direct-Seeded Rice Fields: Implications for Nutrient Budgets and Water Quality. Environ. Qual. 43, 1725-1735.

Mateo-Sagasta, J. \& Burke, J. 2010. Agriculture and water quality interactions: a global overview. SOLAW Background Thematic Report - TR08, (Rome: FAO).

Ministry of Agriculture (MOA), 2016, Agrofood Statistics (Kuala Lumpur: Ministry of Agriculture)

Mohd Noor, M.F, Anja Gassner and Ewald Schnug, 2005, 15 years of precision farming in Europe - lessons to be learned for Malaysia, Landbauforschung Volkenrode, , In Recent Advances in Agricultural Chemistry edited by Haneklaus, S., Rietz, R.M., Rogasik, J., and Schroetter, S., Special Issue 286.

Mohd. Syaifudin A.R., Mohd Sharil Shah M.G., Teoh C.C., Mohamad Aufa M.B., Mohd Nadzim N., Fakrul Radzi F.Z., Mohamad Najib M.Y., Fairol Zamzuri C.S., Abu Hassan D., and Mohd Haffiez A.S., 2016, Variable rate application of fertilizer in rice precision farming Proceeding International Conference on Agricultural and Food Engineering (Cafei 2016), Serdang, Malaysia, August, pp. 277-281.

Nagumo, T., Tajima, S., Chikushi, S. and Yamashita, A., 2013, Phosphorus Balance and Soil Phosphorus Status in Paddy Rice Fields with Various Fertilizer Practices, Plant Prod. Sci. 16(1): 69-76.

Qia, D., Yana, J, and Zhua, J., 2020, Effect of a reduced fertilizer rate on the water quality of paddy fields and rice yields under fishpond effluent irrigation, Agricultural Water Management, 231,1-8

Sawyer, J. E., 1994, Concepts of Variable Rate Technology with Considerations for Fertilizer Application. J. Prod. Agric., 7(2), 195-201

Schumann. A.W., 2010, Precise Placement and Variable Rate Fertilizer Application Technologies for Horticultural Crops. HorTechnology. 20(1), 34-40

UN-Water, 2009, The United Nations World Water Development Report 3: Water in a changing world, (Paris and London: United Nations).

United States Environment Protection Agency (USEPA), 1983, Methods for Chemical Analysis of Water and Wastes, (USA: EPA) 
Wu, H., Zhang, Y., Yuan, Z., and Gao, L., 2016, Phosphorus flow management of cropping system in Huainan, China, Journal of Cleaner Production 112:39-48

Yang, S., Peng, S., Xu, J., He, Y. and Wang, Y, 2013, Effects of water saving irrigation and controlled release nitrogen fertilizer managements on nitrogen losses from paddy fields. Paddy Water Environ. 13: 71-78.

Zebarth, B. J., Drury, C. F., Tremblay, N., and Cambouris, A. N., 2008, Opportunities for improved fertilizer nitrogen management in production of arable crops in eastern Canada: A review, Canadian Journal of Soil Science, 89(2), 113-132

Appendix 1 National Water Quality Standards For Malaysia (selected parameters)

\begin{tabular}{|c|c|c|c|c|c|c|c|}
\hline \multicolumn{8}{|c|}{ CLASSES } \\
\hline PARAMETERS & UNIT & I & IIA & IIB & III & IV & $\mathrm{V}$ \\
\hline $\begin{array}{l}\text { Ammoniacal } \\
\text { Nitrogen }\end{array}$ & $\mathrm{mg} / \mathrm{L}$ & 0.1 & 0.3 & 0.3 & 0.9 & 2.7 & $>2.7$ \\
\hline BOD & $\mathrm{mg} / \mathrm{L}$ & 1 & 3 & 3 & 6 & 12 & $>12$ \\
\hline COD & $\mathrm{mg} / \mathrm{L}$ & 10 & 25 & 25 & 50 & 100 & $>100$ \\
\hline DO & $\mathrm{mg} / \mathrm{L}$ & 7 & $5-7$ & $5-7$ & $3-5$ & $<3$ & $<1$ \\
\hline $\mathrm{pH}$ & & $\begin{array}{c}6.5- \\
8.5\end{array}$ & $6-9$ & $6-9$ & $5-9$ & $5-9$ & - \\
\hline $\begin{array}{l}\text { Elec. Conductivity } \\
*\end{array}$ & umhos/cm & 1000 & 1000 & - & - & 6000 & - \\
\hline $\begin{array}{l}\text { Total Suspended } \\
\text { Solid }\end{array}$ & $\mathrm{mg} / \mathrm{L}$ & 25 & 50 & 50 & 150 & 300 & 300 \\
\hline Temperature (C) & ${ }^{\circ} \mathrm{C}$ & $\mathrm{N}$ & $\begin{array}{l}\text { Normal } \\
+2^{0} \mathrm{C}\end{array}$ & & Normal $+2^{0} \mathrm{C}$ & - & - \\
\hline $\mathrm{Al}$ & $\mathrm{mg} / \mathrm{L}$ & A & - & - & $(0.06) \#$ & 0.5 & - \\
\hline $\mathrm{Cu}$ & $\mathrm{mg} / \mathrm{L}$ & $\mathrm{T}$ & 0.02 & 0.02 & 0.2 & - & - \\
\hline $\mathrm{Mg}$ & $\mathrm{mg} / \mathrm{L}$ & $\mathrm{U}$ & - & - & - & - & - \\
\hline K & $\mathrm{mg} / \mathrm{L}$ & $\mathrm{R}$ & - & - & - & - & - \\
\hline $\mathrm{Fe}$ & $\mathrm{mg} / \mathrm{L}$ & A & 1 & 1 & 1 & $\begin{array}{l}1 \text { (Leaf) } \\
5 \text { (Others) }\end{array}$ & - \\
\hline & & $\mathrm{L}$ & & & & & \\
\hline
\end{tabular}

Department of Environment (2015)

Notes

N : No visible floatable materials or debris or No objectionable odour, or No objectionable taste

* : : Related parameters, only one recommended for use

** : Geometric mean

a : Maximum not to be exceeded

\# $\quad$ : Maximum (unbracket) and 24 - hour average (bracketed) concentrations 
Norlida, M.H. / Effect of different fertilizer management on water quality in the paddy field

Class

Uses

CLASS I : Conservation of natural environment water supply 1 - practically no treatment necessary.

Fishery 1 - very sensitive aquatic species

CLASS IIA : Water Supply II - conventional treatment required

Fishery 11 - sensitive aquatic species

CLASS IIB : Recreational use with body contact

CLASS III : Water Supply 111 - extensive treatment required

Fishery 111 - common, of economic value, and tolerant species livestock drinking

CLASS IV : Irrigation

Appendix 2 Water quality in the inlet, irrigation canal, outlet, and rice plot for two seasons of rice cultivation (average and standard deviation)

\begin{tabular}{|c|c|c|c|c|c|c|c|c|c|c|}
\hline & \multicolumn{2}{|c|}{ Inlet } & \multicolumn{2}{|c|}{ Irrigation Canal } & \multicolumn{2}{|c|}{ Outlet } & \multicolumn{2}{|c|}{ Rice Plot (VR) } & \multicolumn{2}{|c|}{ Rice Plot (UR) } \\
\hline & Season & Season & Season & Season & Season & Season & Season & Season & Season & Season \\
\hline & $2 / 2018$ & $1 / 2019$ & $2 / 2018$ & $1 / 2019$ & $2 / 2018$ & $1 / 2019$ & $2 / 2018$ & $1 / 2019$ & $2 / 2018$ & $1 / 2019$ \\
\hline \multirow[b]{2}{*}{ Temperature $\left({ }^{\circ} \mathrm{C}\right)$} & 29.50 & 29.88 & 29.69 & 28.39 & 29.50 & 28.27 & 28.71 & 27.80 & 28.50 & 27.88 \\
\hline & \pm 1.80 & \pm 1.04 & \pm 2.53 & \pm 1.66 & \pm 3.18 & \pm 1.31 & \pm 2.29 & \pm 0.82 & \pm 2.02 & \pm 0.84 \\
\hline \multirow{2}{*}{ DO (mg/L) } & 5.29 & 6.60 & 6.37 & 4.31 & 4.35 & 2.14 & 5.20 & 1.55 & 3.68 & 1.48 \\
\hline & \pm 1.33 & \pm 0.17 & \pm 3.32 & \pm 2.35 & \pm 2.62 & \pm 1.20 & \pm 4.63 & \pm 1.32 & \pm 3.5 & \pm 1.10 \\
\hline \multirow{2}{*}{ BOD (mg/L) } & 1.51 & 0.88 & 2.98 & 1.60 & 2.55 & 2.24 & 2.34 & 1.82 & 3.21 & 1.77 \\
\hline & \pm 1.18 & \pm 0.28 & \pm 1.40 & \pm 0.75 & \pm 1.84 & \pm 1.49 & \pm 2.25 & \pm 1.22 & \pm 1.71 & \pm 0.74 \\
\hline \multirow{2}{*}{ COD (mg/L) } & 5.14 & 5.31 & 9.35 & 12.79 & 11.93 & 21.15 & 19.01 & 28.34 & 15.94 & 23.21 \\
\hline & \pm 3.13 & \pm 3.79 & \pm 13.80 & \pm 14.41 & \pm 15.29 & \pm 15.30 & \pm 15.27 & \pm 25.88 & \pm 21.33 & \pm 12.82 \\
\hline \multirow{2}{*}{$\begin{array}{l}\text { Ammoniacal Nitrogen } \\
(\mathrm{mg} / \mathrm{L})\end{array}$} & 0.04 & 0.17 & 0.54 & 0.27 & 0.73 & 1.31 & 0.46 & 0.37 & 1.06 & 0.57 \\
\hline & \pm 0.02 & \pm 0.20 & \pm 1.26 & \pm 0.30 & \pm 1.19 & \pm 1.33 & \pm 1.06 & \pm 0.53 & \pm 1.69 & \pm 0.93 \\
\hline \multirow{2}{*}{ TSS (mg/L) } & 25.78 & 61.94 & 16.72 & 12.69 & 34.39 & 32.69 & 33.43 & 27.59 & 26.31 & 43.93 \\
\hline & \pm 8.5 & \pm 67.35 & \pm 14.65 & \pm 9.02 & \pm 28.88 & \pm 16.23 & \pm 27.53 & \pm 39.54 & \pm 18.70 & \pm 88.38 \\
\hline \multirow{2}{*}{$\mathrm{pH}$} & 7.86 & 7.06 & 6.85 & 6.87 & 6.77 & 6.55 & 6.68 & 6.39 & 6.97 & 6.26 \\
\hline & \pm 0.78 & \pm 0.20 & \pm 0.45 & \pm 0.34 & \pm 0.45 & \pm 0.42 & \pm 0.42 & \pm 0.3 & \pm 0.61 & \pm 0.29 \\
\hline \multirow{2}{*}{ Nitrate $(\mathrm{mg} / \mathrm{L})$} & 1.21 & 0.69 & 0.90 & 2.20 & 1.60 & 2.27 & 0.63 & 1.86 & 1.20 & 2.85 \\
\hline & \pm 1.46 & \pm 1.05 & \pm 1.24 & \pm 5.83 & \pm 3.71 & \pm 3.37 & \pm 0.62 & \pm 3.46 & \pm 2.26 & \pm 6.6 \\
\hline \multirow{2}{*}{ Phosphate (mg/L) } & 0.29 & 0.33 & 0.35 & 0.35 & 0.41 & 0.66 & 0.49 & 0.86 & 0.65 & 0.71 \\
\hline & \pm 0.27 & \pm 0.15 & \pm 0.37 & \pm 0.28 & \pm 0.21 & \pm 0.28 & \pm 0.51 & \pm 0.83 & \pm 0.63 & \pm 0.84 \\
\hline \multirow{2}{*}{$\mathrm{Al}(\mathrm{mg} / \mathrm{L})$} & 3.12 & 11.32 & 1.18 & 2.34 & 3.08 & 2.26 & 4.64 & 2.50 & 2.96 & 6.06 \\
\hline & \pm 3.60 & \pm 9.78 & \pm 2.27 & \pm 2.02 & \pm 4.43 & \pm 2.04 & \pm 6.28 & \pm 3.22 & \pm 5.30 & \pm 11.67 \\
\hline \multirow{2}{*}{$\mathrm{Cu}(\mathrm{mg} / \mathrm{L})$} & 0.002 & 0.00 & 0.01 & 0.002 & 0.008 & 0.003 & 0.01 & 0.001 & 0.01 & 0.004 \\
\hline & \pm 0.004 & \pm 0.00 & \pm 0.00 & \pm 0.004 & \pm 0.004 & \pm 0.004 & \pm 0.01 & \pm 0.003 & \pm 0.002 & \pm 0.005 \\
\hline \multirow{2}{*}{$\mathrm{Fe}(\mathrm{mg} / \mathrm{L})$} & 1.68 & 3.96 & 2.00 & 2.66 & 2.84 & 3.66 & 4.54 & 6.73 & 1.67 & 6.71 \\
\hline & \pm 0.73 & \pm 3.41 & \pm 2.28 & \pm 3.06 & \pm 1.91 & \pm 3.30 & \pm 4.29 & \pm 6.78 & \pm 1.33 & \pm 5.45 \\
\hline \multirow{2}{*}{$\mathrm{K}(\mathrm{mg} / \mathrm{L})$} & 7.91 & 2.48 & 8.92 & 2.82 & 10.25 & 3.97 & 9.34 & 2.85 & 10.91 & 2.78 \\
\hline & \pm 3.72 & \pm 2.60 & \pm 5.16 & \pm 3.19 & \pm 6.53 & \pm 4.16 & \pm 4.86 & \pm 3.30 & \pm 8.33 & \pm 3.10 \\
\hline \multirow{2}{*}{$\mathrm{Mg}(\mathrm{mg} / \mathrm{L})$} & 2.02 & 1.38 & 2.22 & 2.09 & 5.87 & 5.93 & 2.66 & 2.12 & 2.98 & 2.46 \\
\hline & \pm 0.81 & \pm 1.05 & \pm 0.63 & \pm 1.68 & \pm 3.06 & \pm 4.54 & \pm 0.74 & \pm 1.41 & \pm 0.9 & \pm 1.36 \\
\hline \multirow{2}{*}{$\mathrm{Mn}(\mathrm{mg} / \mathrm{L})$} & 0.003 & 0.02 & 0.01 & 0.03 & 0.004 & 0.02 & 0.01 & 0.007 & 0.007 & 0.01 \\
\hline & \pm 0.005 & \pm 0.03 & \pm 0.03 & \pm 0.05 & \pm 0.005 & \pm 0.03 & \pm 0.01 & \pm 0.015 & \pm 0.007 & \pm 0.01 \\
\hline
\end{tabular}

